\title{
INVESTIGATING THE RELATIONSHIP BETWEEN LIFESTYLE AND ATTITUDE TOWARDS DEATH: THE CASE OF KERMAN MIDDLE-AGED ADULTS
}

\author{
JAHANGIR JAHANGIRI, FERESHTEH DEHGHANI
}

\begin{abstract}
:
It is obvious that the most personal and most probable inner reality of human beings is death which is being kept hidden from public view and considered as a marginalized issue due to changes occurred in societies. This has led to a change in individuals' attitudes towards death, which is apparently influenced by social and cultural factors. Therefore, this research aimed to measure individuals' attitudes towards death and to explore the relationship between lifestyle and attitudes towards death and its variants. In this survey study, 415 middle-aged adults aged 40-65 years were studied in Kerman. Descriptive statistics of the study showed that $14 \%, 68.7 \%$, and $17.3 \%$ of the respondents had negative, neutral, and positive attitudes towards death, respectively. The relationship between lifestyle and attitudes towards death and its variants was confirmed; however, the relationship between demographic variables (gender, marital status, level of education, and income) and attitudes towards death was rejected and their relationship with attitude variants was confirmed. Twelve percent of dependent variable variance was explained by four variables (namely body management, leisure-time activities, consumption of cultural goods, and gender). Concerning the variants of attitudes towards death, some variances of the variables fear of death (5\%), death avoidance $(6.1 \%)$, escape acceptance $(4.5 \%)$, approach acceptance $(8.7 \%)$, and neutral acceptance $(13 \%)$ were also explained by the independent variables consumption of cultural goods, leisure-time activities, body management, gender, marital status, level of education and income.
\end{abstract}

\section{Keywords:}

Death, attitude, lifestyle, fear, avoidance, acceptance

JEL Classification: Z13, I10

\section{Authors:}

JAHANGIR JAHANGIRI, Shiraz University, Iran (Islamic Republic of), Email: jjahangiri@gmail.com FERESHTEH DEHGHANI, Shiraz University, Iran (Islamic Republic of), Email:

freshteh.dehghani@yahoo.com

\section{Citation:}

JAHANGIR JAHANGIRI, FERESHTEH DEHGHANI (2017). Investigating the Relationship between Lifestyle and Attitude towards Death: The Case of Kerman Middle-Aged Adults. International Journal of Social Sciences, Vol. VI(1), pp. 20-40., 10.20472/SS.2017.6.1.003 


\section{Introduction}

For ever since the creation of the universe, no more critical question has been raised than the ones associated with death and the final destiny of human beings. Further, no event has obsessed human beings' minds as much as death. Throughout the history, people have paved different ways to overcome this phenomenon and have held different attitudes towards death. Today, the number of violent and horrific deaths has increased due to technological changes so that people have not been exposed to the danger of death as much as these days.

In the global communication village, the death is surrounding us with horrific details (Wong and Tomer, 2011). In this modern industrial society, we are facing ubiquitous risks. According to Ulrich Beck, child mortality, infectious diseases and natural disasters have steadily decreased with the society industrialization; however, new risks have emerged (Duncan, 1999). Situations such as terrorist threats, wars, accidents and the like clearly reveal the human life instability and destruction (Routledge and Juhl, 2010). The widespread presence of death in the social world continuously reminds us the fact that death is inevitable and we definitely experience it sooner or later. The significant point is this regard, however, is that, despite its inevitability, we always escape it. This becomes more critical when, in spite of 30 thousand deaths from cancer (Hamshahri Online News Agency, February 1, 2015, News ID: 286012), 17 thousand deaths caused by road accidents (IRNA News Agency, March 20, 2015, News ID: 81547525), annual assassination of over a thousand people in Iran (Aftab News Agency, April 6, 2014, News ID: 238274) and Iran's being ranked 48 in the world in terms of the suicide (Salamat News Agency, April 25, 2014, News ID: 110279) and so on, no precautions are considered in this case and it is indifferently ignored. Given that we do not take the death into consideration in spite of the aforementioned events, the question raised is as follows: What attitudes do we hold towards death?

Although death is a natural phenomenon in the sense that each living creature will die, it is a social and cultural phenomenon or a social construction from the perspective of social sciences. It means that this apparently natural and biological inevitable phenomenon is constructed under cultural, social, and historical circumstances (Jacobson, 2013). Modernity is one of such social and cultural contexts.

Modernity not only has created new experiences but also has transformed the past experiences and shaped them as itself. In the modern world, death has become a taboo and its experience has been impressed in the minds of individuals and the public. Baudrillard believes that human beings during an irreversible process have thrown out the dead from their homes into the city and then outside the city, i.e. out of the life cycle of living. In media, death is described mostly as tragic, terrible, unjust, unwanted and rarely as relaxing. People try to control environmental factors and to escape death through any possible way (Karimi, 2009). Nowadays, therefore, the most common response to the death is avoidance and fear. 
Researchers have repeatedly stated that individuals in modern societies either deny death or fear from it and the fears may lead to alienation and nihilism (Carr, 2012). The problem with death denial is that the more we try to quell the death, the more different varieties of anxiety can manifest themselves as worry, depression, tension and conflict. Another problem with the death denial is its being doomed to failure because life events such as incurable diseases or the death of our beloved expose us with the grim reality of death sooner or later (Wong and Tomer, 2011). Hence, the best and most effective way to reduce the problems caused by negative attitudes towards death is accepting death.

Wong (1994) suggests when we accept our death, we declare our inevitable intention to invest on our time and energy for a good life and not to defend ourselves against death. He also added that accepting death protects us against anxiety and boosts our energy to have a purposeful and happy life. He believes that the acceptance of death is one of the foundations in a desirable life (Parker, 2013).

There is mounting evidence that social cognition and behavior are affected by the acceptance of death. For example, benevolence in the form of almsgiving was encouraged among those individuals with the memories of the death compared to the control group (Siyang Luo, 2014). At the cultural level, the acceptance of death appears in a wide variety of social functions such as family, religion, and medical care (Wong and Tomer, 2011). Hence, investigating some ways to promote the positive aspects of the acceptance of death is necessary. Many studies have highlighted the effect of the identity on the acceptance of death because the death challenges identity. In fact, death raises questions challenging the basic assumptions of construction of the social life. Death would pose the questions that distort the sociallyconstructed image of the reality. Anomic power of the death penetrates into the innermost aspects of an individuals' identity (Mellor, 1992). Hence, individuals should create their identities through using reflexive mechanisms and available socio-cultural resources (Giddens, 2009). One of these mechanisms and socio-cultural resources is lifestyle.

Lifestyles as the projects forming identity can reveal individuals' differences and distinctions. The lifestyle is not an imposed and assigned pattern accepted by individuals, based on which they behave. Today, individuals belonging to different social groups do not behave passively in dealing with various lifestyles; however, they are noticeably creative, using their own agency to create and select new life styles in order to make a distinction between themselves and others and to shape a new life and identity (Bayengani, Irandoust and Ahmadi, 2013).

We are also living in a society progressing towards modernization and acquiring modern values. The resulting changes and developments have affected many aspects of social life, including attitudes towards death. Consequently, this study was to measure attitudes towards death and to investigate the relationship between lifestyle as a cultural source of identity and attitude towards death. Regarding the dearth of sociological research on this field in Iran and concerning the fact that attitude towards 
death becomes more important since the beginning of aging and with the special problems of this period, this study focused on investigating the relationship between lifestyle and attitude towards death among Kerman middle-aged adults as future elderly.

\section{Review of the literature}

A thorough review of the empirical literature revealed no study investigating the relationship between lifestyle and attitude towards death. Some studies which may contribute to the present study are as follows.

In a study conducted in Imam Khomeini Hospital on making the process of death meaningful for the cancer patients, it was found that, of the outstanding plays mentioned by Susan Lang, dramas associated with religion and medicine are of greater impact in Iran, which reflects the gap between the old tradition and modernism (Ghaneirad and Karimi, 2006). The results of another study indicated that the Bam students who had experienced the death were less afraid than Kerman students who did not have such an experience. In both groups participating in this study, those students who were trained on death had more positive attitudes towards death (Bagherian, Iranmanesh and Abbas Zadeh, 2009). Further, research showed that there is a significant relationship between quality of life and some of its aspects (general health, physical limitations, tiredness or vitality) with attitudes towards death in the elderly (Poorgholami, Sohrabi Shekofti and Samani, 2011). These results indicated that the study participants were similar in terms of acceptance of death, belief in the afterlife, concerning death, fear of death and desire a long life and different in terms of death image (time, place and form). These distinctions are influenced by religious understanding and the families play a vital role in this regard (Yousefi and Tabei, 2011). In another study, it was suggested that there was no significant difference between Asian and American students regarding attitudes towards death; however, Asian students were more afraid of the process of dying than American students (Kao and Lusk, 1997). Lavoie and Vries (2004) concluded that personal identity is related to the acceptance of death. Maria et al. (2011) also showed a significant relationship between patient advocacy groups and lower levels of fear of death. The results of two other studies also showed that integration, i.e. the ability to accept the past, increases the probability of acceptance of death (Parker, 2013 and Nakagi and Tada, 2014).

\section{Theoretical Framework}

In this section, we tried to seek a theory that best explain the subject of our choice. To this end, Bourdieu's Lifestyle Theory and Wong and Elias' theories on attitude towards death were selected in this study. Bourdieu's contains the most comprehensive analysis on the lifestyle and attitude and Wong's consists of the most detailed 
classification provided on attitudes towards death. However, since Wong's theory is a social psychology theory, Elias' theory was added to the theoretical framework to explain sociological aspects of attitudes towards death.

Bourdieu believes that individuals and groups acquire a certain status in social classifications based on their differentiated position in the social space and through internalizing this position and its symbols (habitus). According to this theory, some preferences and tastes are formed in individuals' minds and actions, which are sometimes distinct from and in conflict with other groups and individuals'. They emerge in terms of actions and activities which result in distinct and diverse lifestyles (Nosrati and Zolfaghari, 2012).

These different lifestyles reproduce the habitus because the lifestyle is a space, based on which the actors learn how to live, what to prioritize, and what is beautiful (Jamshidiha and Parastesh, 2007). As a result, various lifestyles form different habitus.

Habitus is a socially constructed vision of the world, viewed as 'natural' rather than consciously conceived, and involving 'the embodiment within individuals of systems of social norms, understandings and patterns of behavior ... ensuring that individuals are more disposed to act in some way than others' (Flint, 2003). Meaningful experiences and meaning-giving perception are created by the habitus (Christensen and Carpiano, 2014).

The habituses are the products of situations, and similarly are segregated and segregating. The habituses are distinctive, differentiating and distinguishing factors: They employ different principles of distinction or similar principles of distinction in different ways. Habituses also refer to the classification schemas, principles of classification, principles of viewing and sharing, and principles of different tastes. They also distinguish between good and bad, good and evil, honorable and vulgar, etc. (Bonnewitz, 2012). Death is one of such cases.

Death is an integral part of human life and people hold different attitudes towards death on the basis of their lifestyles and habituses. How people view life depends upon their lifestyle. Thus, individuals' consumption of cultural goods, body management, leisure-time activities and ... form their different habituses, which marking different attitudes towards death.

According to Wong, there are five different types of attitudes held towards death. He believes that attitudes towards death include not only fear of death and death avoidance but also acceptance of death. There are also different types of acceptance: Neutral acceptance, approach acceptance and escape acceptance. In different situations of life, people are willing to accept death or to fear from it. Neutral attitudes are healthier and safer because a person regards death as something natural and inevitable (Chistopolskaya and Enikolopov, 2013). 
Different attitudes towards death not only are affected by different lifestyles but also stem from the social conditions underlying these styles. Modern and less modern (traditional) contexts transform individuals' lifestyles and their lifestyles include a range of contexts from traditional to modern. Consequently, individuals' attitudes towards death are also changed. Therefore, the society and its changes have an effect on individuals' attitudes towards death. Elias believes that modernity has changed people's attitudes towards death. In traditional societies, the death was considered as a stage to enter into another world; however, it is denied in modern societies.

He believes that, consistent with a significant leap in the process of civilization initiated four or five centuries ago, peoples' attitudes towards death and form of death have also changed like many other cases. Over the earlier ages, death used to occur in public places. Birth and death were occurring in public places; therefore, they were more social concepts than they are today. These events were not private. Adults' reluctance to familiarize children with the death-related facts is the most outstanding features of modern attitudes towards death. This suppression or repression of death at individual and social levels is worthy of attention (Elias, 2006).

Iranian attitudes towards death can be explained by many different factors; however, one of the most important factors is associated with individuals' differences at cultural levels. Due to containing traditional and modern elements together and having ethnic and cultural diversity, Iran consists of various lifestyles ranging from traditional to modern. Hence, people hold different attitudes towards death. 


\section{Research model}

\begin{tabular}{|l|l|}
\hline Demographic Variables & \\
\hline Gender & \\
\hline Marital status & Attitude towards death \\
\hline Level of Education & Fear of death \\
\hline Income & Death Avoidance \\
\hline Lifestyle & Approach Acceptance \\
\hline Consumption of cultural goods & Neutral Acceptance \\
\hline Leisure-time activities & Escape Acceptance \\
\hline Body management & \\
\hline
\end{tabular}

\section{Main Research Hypothesis}

There is a relationship between lifestyle (its dimensions) and attitude towards death (its dimensions).

\section{Secondary Research Hypothesis}

There is a relationship between demographic variables (gender, marital status, level of education and income) and attitudes towards death and its variants.

\section{Research Method}

The population of this survey study consisted of middle-aged adults living in Kerman. Ericsson Theory was employed for the aim of this study, which holds that middle age begins at 40 years and continues until 65 years. Hence, the population of this study contains adults aged 40-65 years in Kerman. According to Iran Statistics Center website, it includes 141212 persons (70721 female and 70491 male). With regard to the Cochran's formula, the sample size was estimated to be 383 with confidence level of $95 \%$ and a margin error of $5 \%$. For the sake of reliability, the sample size increased to 415 subjects. Multi-stage cluster sampling was also used. This means that, in order to distribute and collect the questionnaires, four districts of Kerman were first selected and then smaller blocks were considered as a cluster within each district proportional 
to the number of the households. After that, the households of the clusters were analyzed. Formal methods were also selected to test the validity of the items. The items were of high reliability and Cronbach's alpha was used to measure it.

\section{Definition of Key Terms}

Lifestyle: Bourdieu defines lifestyle as the assets possessed by individuals, including house, villa, yacht, car, furniture, paintings, books, drinks, cigarettes, perfumes, and clothes. Then, he adds that it includes the activities by which an individual differentiates himself. They include sports, games, entertainment, dress, appearance and body, use of language and budgeting (Mahdavi Kani, 204: 2007). Lifestyle is measured based on a Likert scale with 29 items.

Traditional lifestyle: This style contains the elements of the historical past and cultural symbols, in which a kind of life is illustrated and the consumption patterns, tools, features and behaviors represent traditional ways of life with their own efficiencies. Its associated 8 items are measured based on a Likert scale.

Modern life style: This style indicates the presence of elements of modern life, representing a forward-looking perspective. It is formed by the use of modern tools and devices, the use of art formats, modern leisure time, attention to the values such as gender equality, welfare and the like (Rasouli, 62: 2003). Its associated 21 items are measured based on a Likert scale.

Attitude towards death: Attitudes towards death can be defined as an individuals' perception, feeling or reaction towards death. According to Wong, it can be classified into five different types: fear of death, death avoidance, escape acceptance, approach acceptance, and neutral acceptance. This variable was measured based on Wong's Death Attitude Profile-Revised (DAP-R) Scale. These types of attitudes towards death are defined as follows:

Fear of death: It refers to holding negative thoughts and feelings towards death. The variable is assessed in the form of a 5-point Likert scale with 7 items.

Death avoidance: It means to dodge the issue. The variable is assessed in the form of a Likert scale with 5 items.

Approach acceptance: It is defined as the acceptance of death as a way to a better world. It is measured on a Likert format with 10 items.

Neutral acceptance: It means facing death rationally as an inevitable end of life. Neutral acceptance is measured on a Likert format with 5 items.

Escape acceptance: This variable indicates choosing death as a better alternative to suffering and pain. It is measured on a Likert format with 5 items. 


\section{Descriptive Statistics}

The study data was extracted from the questionnaires completed by 415 middle-aged adults in Kerman. The collected data were analyzed. Descriptive findings of this study showed that the participants were female $(52.5 \%)$ and male $(47.5 \%)$. A majority of the participants were married (88.7\%) and $38.3 \%$ of the participants were holding associate's and bachelor's degrees. Most respondents (41 percent) had income levels between 1-2 million Tomans. The highest frequency ( 65.8 percent) was relevant to the respondents with medium levels of body management and the majority of the respondents (64.3\%) consumed cultural goods at an average level. Regarding leisuretime activities, the highest frequency $(62.9 \%)$ was allocated to those spending their leisure time in an eclectic form. Concerning individuals' lifestyle, the highest frequency $(66.5 \%)$ was also associated with those having an eclectic lifestyle. The mean scores obtained for the variants of attitudes towards death are as follows: Fear of death $(2.72 \%)$, death avoidance $(2.71 \%)$, escape acceptance $(2.88 \%)$, approach acceptance (3.84\%), and neutral acceptance (4.03\%). In general, $14 \%, 68.7 \%$, and $17.3 \%$ of the respondents had negative, neutral, and positive attitudes towards death, respectively.

\section{Inferential Statistics}

The study hypotheses were tested using comparison of means, univariate analysis of variance (ANOVA), multivariate analysis of variance (MANOVA) and Pearson correlation coefficient. Table 1 outlines the relationship between lifestyle and its variants and attitudes towards death and its various types. The results revealed that there is a significant correlation between lifestyle and attitudes towards death as the more modern one's lifestyle is, the more negative his attitude is towards death. The relationship observed between approach acceptance and lifestyle was negative; however, there was a significant direct relationship between lifestyle and death avoidance. Moreover, there is an inverse relationship between body management and fear of death, i.e. the increased levels of the body management reduce fear of death. A direct relationship also existed between the consumption of cultural goods and attitudes towards death. The consumption of cultural goods had significant inverse and direct relationships with approach acceptance and death avoidance, respectively. Moreover, there was a relationship between leisure-time activities and attitudes towards death, as the more modern one's leisure-time activities are, the more negative his attitude towards death is. There was a direct relationship leisure-time activities and approach acceptance; however, it was inversely related to death avoidance. 
Table 1: Pearson correlation test performed between independent variables and attitudes towards death as well as its variants

\begin{tabular}{|c|c|c|c|c|c|c|c|}
\hline $\begin{array}{l}\text { Dependent } \\
\text { variables } \\
\text { Independent } \\
\text { variables }\end{array}$ & $\begin{array}{l}\text { Sig } \\
\& R\end{array}$ & $\begin{array}{l}\text { attitude } \\
\text { towards } \\
\text { death }\end{array}$ & $\begin{array}{c}\text { Death } \\
\text { Avoidance }\end{array}$ & $\begin{array}{c}\text { Neutral } \\
\text { Acceptance }\end{array}$ & $\begin{array}{c}\text { Approach } \\
\text { Acceptance }\end{array}$ & $\begin{array}{c}\text { Escape } \\
\text { Acceptance }\end{array}$ & $\begin{array}{c}\text { Fear } \\
\text { of } \\
\text { death }\end{array}$ \\
\hline \multirow[t]{2}{*}{ lifestyle } & $\mathrm{R}$ & .137 & .171 & .035 & -.139 & .076 & -.094 \\
\hline & sig & .005 & .000 & .482 & .005 & .120 & .057 \\
\hline \multirow{2}{*}{$\begin{array}{l}\text { Consumption } \\
\text { of cultural } \\
\text { goods }\end{array}$} & $\mathrm{R}$ & -.120 & .150 & .032 & -.193 & -.042 & .008 \\
\hline & sig & .015 & .002 & .532 & .000 & .398 & .869 \\
\hline \multirow{2}{*}{$\begin{array}{c}\text { Body } \\
\text { management }\end{array}$} & $\mathrm{R}$ & .418 & .039 & .099 & .009 & -.003 & -.159 \\
\hline & sig & .040 & .432 & .052 & .855 & .957 & .001 \\
\hline \multirow{2}{*}{$\begin{array}{l}\text { Leisure-time } \\
\text { activities }\end{array}$} & $\mathrm{R}$ & .155 & .155 & .031 & -.144 & .039 & .045 \\
\hline & sig & .002 & .002 & .534 & .003 & .434 & .364 \\
\hline
\end{tabular}

Two-sample T-test was performed for gender (as a variable). Further, univariate analysis of variance (ANOVA) was conducted for the variables marital status, level of education, and monthly income with regard to the general attitude towards death. Table 2 represents the mean scores of the variable gender, indicating that the mean score of attitude towards death was higher for women than men. Considering the Ttest results, the difference between two mean scores is significant at $95 \%$. Regarding ANOVA test and F-values reported, there was no significant difference between individuals' attitude towards death with respect to their marital status, education or income. This insignificancy can be attributed to five different types of attitudes towards death since the respondents had fewer options for attitudes towards death while integrating these five variants, resulting in neutral attitudes towards death for a majority of respondents. This led to non-significant differences in respondents' attitudes with respect to individual and background variables. 
Table 2: Mean difference test of attitudes towards death with regard to gender, marital status, level of education and income

\begin{tabular}{|c|c|c|c|c|c|c|}
\hline \multicolumn{2}{|c|}{ Independent variable } & frequency & Mean & $\begin{array}{l}\text { standard } \\
\text { deviation }\end{array}$ & T-value & Sig. \\
\hline \multirow[b]{2}{*}{ Gender } & Female & 218 & 3.37 & .30 & \multirow[b]{2}{*}{2.033} & \multirow[b]{2}{*}{.043} \\
\hline & Male & 197 & 3.311 & .28 & & \\
\hline
\end{tabular}

Multivariate analyses of variance are shown in Table (3), concerning differences between attitudes towards death with regard to gender, gender, marital status, level of education and income. Wilks' lambda value was equal to .977 , with $F=1.941$, indicating no significant difference for gender at .087. Furthermore, considering the Wilks' lambda value, F-value, and significance level reported for the variables marital status, level of education and income, it can be mentioned that Wilks' lambda value revealed a significant difference between the levels of independent and dependent variables. Wilks' lambda value shows the extent not explained for the dependent variables by the independent variables, and deducting this value from 100 represent the extent explained. Partial Eta Squared and observed values are approximately one, indicating significant differences between levels of marital status, education and income with regard to the dependent variables. Since multivariate tests assess different aspects and types of dependent variables in comparison with each other, not separately, the results of the multivariate test and tests performed for different aspects may vary. Table 4 shows the relationship between the independent variable and each aspect of the dependent variable separately.

Table 3: Multivariate analysis on different variants of attitudes towards death

\begin{tabular}{|c|c|c|c|c|c|c|c|}
\hline 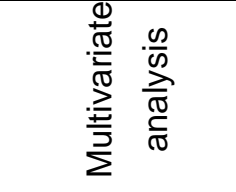 & 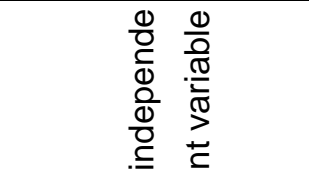 & $\frac{\frac{\Phi}{T}}{\stackrel{N}{>}}$ & 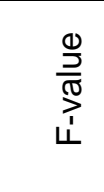 & 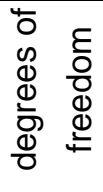 & $\dot{\infty}$ & 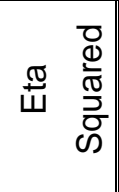 & $\begin{array}{ll}0 & \\
0 & \\
\sum_{0}^{\infty} & \overline{0} \\
\infty & 0 \\
0 & 0 \\
0 & 0\end{array}$ \\
\hline \multirow{4}{*}{ Wilks' lambda } & Gender & .977 & 1.941 & 5 & .087 & .023 & .655 \\
\hline & Marital status & .890 & 3.212 & 15 & .000 & .038 & .998 \\
\hline & Level of education & .873 & 2.801 & 20 & .000 & .033 & .997 \\
\hline & income & .893 & 2.344 & 20 & .002 & .028 & .986 \\
\hline
\end{tabular}

Table 4 represents the univariate analysis of gender, marital status, level of education, and monthly income with regard to various types of attitudes towards death. Univariate 
analysis showed that the only significant differences were observed between the respondents' gender and approach acceptance as well as between the respondents' marital status and death avoidance, neutral acceptance and escape acceptance. Regarding different aspects of the dependent variable, a significant difference was shown between the level of education and the acceptance of impartial and death avoidance and escape acceptance. Univariate analysis showed that there was no significant difference between different levels of income in terms of the aforementioned types of attitudes towards death.

Table 4: Univariate analysis on gender, marital status, level of education and income

\begin{tabular}{|c|c|c|c|c|c|c|}
\hline $\begin{array}{l}\text { Independent } \\
\text { variables }\end{array}$ & $\begin{array}{l}\text { Dependent } \\
\text { variables }\end{array}$ & $\begin{array}{l}\text { Mean } \\
\text { square }\end{array}$ & F-value & Sig. & $\begin{array}{c}\text { Partial eta } \\
\text { squared }\end{array}$ & $\begin{array}{c}\text { Observed } \\
\text { value }\end{array}$ \\
\hline \multirow{5}{*}{ Gender } & $\begin{array}{l}\text { Fear of } \\
\text { death }\end{array}$ & 1.612 & 2.366 & .125 & .006 & 336 \\
\hline & $\begin{array}{c}\text { Death } \\
\text { Avoidance }\end{array}$ & .004 & .006 & .939 & .000 & .051 \\
\hline & $\begin{array}{l}\text { Approach } \\
\text { Acceptance }\end{array}$ & 3.409 & 5.794 & .017 & .014 & .671 \\
\hline & $\begin{array}{c}\text { Neutral } \\
\text { Acceptance }\end{array}$ & .008 & .018 & .894 & .000 & .052 \\
\hline & Escape & 2.153 & 3.461 & .064 & .008 & .459 \\
\hline \multirow{5}{*}{ Marital status } & $\begin{array}{l}\text { Fear of } \\
\text { death }\end{array}$ & 1.096 & 1.608 & 187 & .012 & .423 \\
\hline & $\begin{array}{c}\text { Death } \\
\text { Avoidance }\end{array}$ & 2.297 & 3.257 & .022 & .023 & .746 \\
\hline & $\begin{array}{l}\text { Approach } \\
\text { Acceptance }\end{array}$ & 1.052 & 1.756 & 153 & .013 & .460 \\
\hline & $\begin{array}{c}\text { Neutral } \\
\text { Acceptance }\end{array}$ & 2.563 & 5.737 & .001 & .041 & .949 \\
\hline & $\begin{array}{c}\text { Escape } \\
\text { Acceptance }\end{array}$ & 3.146 & 5.139 & .002 & .036 & .922 \\
\hline
\end{tabular}




\begin{tabular}{|c|c|c|c|c|c|c|}
\hline \multirow{5}{*}{$\begin{array}{l}\text { Level of } \\
\text { education }\end{array}$} & $\begin{array}{l}\text { Fear of } \\
\text { death }\end{array}$ & .868 & 1.273 & 280 & .012 & .399 \\
\hline & $\begin{array}{c}\text { Death } \\
\text { Avoidance }\end{array}$ & .457 & .633 & 639 & .006 & 208 \\
\hline & $\begin{array}{l}\text { Approach } \\
\text { Acceptance }\end{array}$ & .808 & 1.361 & .274 & .013 & .425 \\
\hline & $\begin{array}{c}\text { Neutral } \\
\text { Acceptance }\end{array}$ & 3.856 & 8.801 & .000 & .079 & .999 \\
\hline & $\begin{array}{c}\text { Escape } \\
\text { Acceptance }\end{array}$ & 1.758 & 2.856 & .023 & .027 & .755 \\
\hline \multirow{5}{*}{ income } & $\begin{array}{l}\text { Fear of } \\
\text { death }\end{array}$ & .954 & 1.401 & .302 & .013 & .437 \\
\hline & $\begin{array}{c}\text { Death } \\
\text { Avoidance }\end{array}$ & 1.099 & 1.538 & .092 & .015 & . 476 \\
\hline & $\begin{array}{c}\text { Approach } \\
\text { Acceptance }\end{array}$ & 1.599 & 2.732 & .09 & .026 & .574 \\
\hline & $\begin{array}{c}\text { Neutral } \\
\text { Acceptance }\end{array}$ & .756 & 1.635 & 0.174 & .016 & .503 \\
\hline & $\begin{array}{c}\text { Escape } \\
\text { Acceptance }\end{array}$ & 1.606 & 2.607 & .051 & .025 & .731 \\
\hline
\end{tabular}

\section{Multivariate Regression}

In this study, stepwise regression method was used. Multivariate regression analyses of independent variables are presented in Table 5. It should be noted that multivariate linear regression was selected for this study due to the multi-dimensional nature of the dependent variable. The results of the analyses are presented for different aspects of attitudes towards death and the general attitude towards death.

As it can be observed in Table 5, five percent of the variance observed for the fear of death can be explained only by three variables (namely body management, income and gender). Beta value showed that, of the three variables included in the model, body management has a negative relationship with the dependent variable and other two variables are positively correlated. T-test results also revealed that the beta coefficients for these variables are statistically significant at the minimum confidence 
level of $95 \%$. Regarding the death avoidance, it can be said that, of all independent variables included, only the variables modern leisure-time, marital status and level of education remained, explaining $6.1 \%$ of the variances observed for this variable. Furthermore, the three variables entered into the model had a positive relationship with the death avoidance and the beta coefficient for these variables was statistically significant at the minimum confidence level of $95 \%$. In terms of escape acceptance, only the variables marital status and level of education remained, which account for 4.5 percent of the variance. The variable escape acceptance had a negative and positive relationship with the variables level of education and marital status, respectively. Beta coefficients for these two variables are at the minimum confidence level of $95 \%$. In the case of neutral acceptance, the variables marital status, income and level of education remained, explaining 13 percent of variance observed for this variable. The variables marital status and level of education were negatively correlated with the variable neutral acceptance; however, it was positively correlated with the variable income. Beta coefficients for these three variables were significant at the minimum confidence level of $95 \%$. Considering the variable approach acceptance, only three independent variables (namely consumption of cultural goods, leisure-time activities and gender) were regarded, accounting for 8.7 percent of the variance observed. There was a negative relationship between consumption of cultural goods, gender, and approach acceptance. On the other hand, approach acceptance and leisure-time activities were positively correlated. Beta coefficients estimated for these three variables were significant at the minimum confidence level of $95 \%$. Regarding the variable attitudes towards death, of all independent variables entered, only the variables traditional leisure-time activities, consumption of cultural goods, gender and body management were specified, which accounted for $12 \%$ of the observed variance. The variable consumption of cultural goods was negatively correlated with this variable and the other remaining variables traditional leisure-time activities, gender, and body management were positively correlated with attitude held towards death. Beta coefficients estimated for the four variables were significant at the minimum confidence level of $95 \%$.

Table 5: Multivariate Regression of attitudes towards death and general attitude

\begin{tabular}{|c|c|c|c|c|c|c|c|c|c|}
\hline $\begin{array}{c}\text { Dependent } \\
\text { variable }\end{array}$ & Included Variable & $\mathrm{R}$ & $\mathrm{R}^{2}$ & $\begin{array}{l}\mathrm{R}^{2} \\
. \mathrm{Ad}\end{array}$ & $\begin{array}{c}\text { Standard } \\
\text { error }\end{array}$ & B & Beta & $\mathrm{T}$ & Sig. \\
\hline \multirow{2}{*}{$\begin{array}{l}\text { Fear of } \\
\text { death }\end{array}$} & Body & .153 & .023 & .021 & .825 & -.230 & -.181 & -3.594 & .000 \\
\hline & Income (1-2 & .187 & .035 & .030 & .821 & .216 & .127 & 2.517 & .012 \\
\hline \multirow{2}{*}{$\begin{array}{c}\text { Death } \\
\text { Avoidance }\end{array}$} & Leisure-time & 0.170 & 0.029 & .026 & .841 & .324 & .194 & 3.733 & .000 \\
\hline & Marital status & 0.221 & 0.049 & .044 & .833 & .549 & .142 & 2.890 & .004 \\
\hline
\end{tabular}




\begin{tabular}{|c|c|c|c|c|c|c|c|c|c|}
\hline & $\begin{array}{c}\text { Level of } \\
\text { education (less }\end{array}$ & 0.246 & 0.061 & .053 & .829 & .281 & .116 & 2.328 & .020 \\
\hline \multirow{2}{*}{$\begin{array}{c}\text { Escape } \\
\text { Acceptance }\end{array}$} & Marital status & .173 & .030 & .027 & .780 & .585 & .163 & 3.272 & 0.001 \\
\hline & $\begin{array}{l}\text { Level of } \\
\text { education }\end{array}$ & .212 & .045 & .040 & .775 & -.306 & -.122 & -2.45 & 0.015 \\
\hline \multirow{3}{*}{$\begin{array}{c}\text { Neutral } \\
\text { Acceptance }\end{array}$} & $\begin{array}{c}\text { Level of } \\
\text { eduration }\end{array}$ & .282 & .080 & .077 & .663 & -.388 & -.259 & -5.386 & .000 \\
\hline & Marital status & .323 & .104 & .100 & .654 & -.479 & -.153 & -3.167 & .002 \\
\hline & Income (1-2 & .360 & .130 & 121 & 647 & 142 & .101 & 2.108 & .036 \\
\hline \multirow{3}{*}{$\begin{array}{c}\text { Approach } \\
\text { Acceptance }\end{array}$} & Consumption of & .213 & .045 & .043 & .760 & -.298 & -.179 & -3.666 & .000 \\
\hline & $\begin{array}{c}\text { Leisure-time } \\
\text { activities } \\
\text { (traditional) }\end{array}$ & .254 & .064 & .059 & .753 & .197 & .140 & 2.889 & $0 / 004$ \\
\hline & Gender (female) & .294 & .087 & .080 & .745 & -.350 & -.156 & -3.196 & 0020 \\
\hline \multirow{4}{*}{$\begin{array}{c}\text { Attitude } \\
\text { towards } \\
\text { death }\end{array}$} & $\begin{array}{c}\text { Leisure-time } \\
\text { sntivitioc }\end{array}$ & .173 & .030 & .027 & .780 & .585 & .163 & 3.272 & .000 \\
\hline & Consumption of & .223 & .050 & .042 & .295 & .073 & -.121 & .413 & 0.001 \\
\hline & & & & & & & & & \\
\hline & Body & .323 & .12 & .095 & .739 & .207 & -.135 & .769 & .021 \\
\hline
\end{tabular}

\section{Conclusion}

Modernity has brought about various changes in different fields so that many unimportant issues of the past are significant social matters nowadays. Further studies and investigations are required to find the relevant factors and fundamental solutions. One of these issues is death and its associated factors, which have raised many problems in the societies.

Death is a social and cultural issue. Not only the death stages can be considered for each individual, but also different ways of death and dying are taught as a result of internalized socialization. That is why they differ in different societies. Furthermore, its sense and sense-making forms change over time in each community. For example, 
time and place of death as well as previous causes of deaths have changed in modern societies. Moreover, recalling the death and being exposed to it are prevented in modern societies. This has led to the transformation of the life and death experience, since death is an undeniable reality. Therefore, this study was to investigate individuals' attitude towards death and its relationship with lifestyle as a relevant cultural factor. In this study, Bourdieu, Wong and Elias' theories were used.

Results of the study indicated a relationship between lifestyle and attitude towards death, particularly death avoidance and pleasant acceptance. This means that the more modern one's lifestyle is the more negative his attitude is towards death. The more traditional lifestyle is also associated with more positive attitude and approach acceptance. According to Bourdieu's theory, lifestyles would result in the reproduction of habituses as a set of moods presented in the actor's personality directing his behavior in different situations. One of such situations is how to deal with death; therefore, the relationship between lifestyle and attitude towards death can be justified. In addition, Elias believes that there is a strong tendency to deny death in today's societies. Death in modern societies is ignored and suppressed both at individual and social levels (Elias, 2006). The modern lifestyle is directly correlated with death avoidance, i.e. to evade death. Elias also claims that suppressing death in the past societies was in a form of belief in immortality and the idea of life in another world. Consequently, it can be claimed that the traditional lifestyle is correlated with approach acceptance of death, i.e. accepting death as a gateway to another world.

The results also showed that the consumption of cultural goods is directly correlated with more negative attitudes towards death. It also has a direct relationship with death avoidance and an indirect relationship with approach acceptance. There are also correlations between more modern leisure-time activities and more negative attitudes towards death and death avoidance; also between more traditional leisure-time activities and approach acceptance. As Elias' Theory put forth, it can be suggested that there are correlations between higher consumption of cultural goods and more modern forms of leisure-time activities and death avoidance as a feature of modern societies. Lower consumption of cultural goods and more traditional forms of leisuretime activities are also correlated with the approach acceptance as a feature of traditional societies.

With regard to the results of the study, a negative and significant relationship exists between body management and fear of death. Body management as one of the lifestyle factors is associated with attitudes towards death and this finding can be confirmed. The finding that body management is associated with the fear of death but not with other types can be justified, since middle-aged adults regard the body management as a health and sanity-related issue. Obviously, more attention to the body and oneself results in holding better feelings towards the body. This decreases the fear of the destruction of the body in individuals. In the current study, weak correlation between lifestyle and the dimensions of the attitude towards death requires further discussion. This may be due to the fact that Iran is a society integrated with 
tradition and modernity so that many moderns in Iran are still traditional and some of our traditions also include modernity representations. As the descriptive statistics showed a majority of respondents had an eclectic lifestyle and there was little difference between them in terms of lifestyle. Regarding the theoretical framework, lifestyle variations may change attitudes towards death. Since there has been little change in lifestyle, no great change in attitude towards death is observed. On the other hand, in addition to traditional and modern values, an Iranian society is also influenced by religion. In fact, religion is a crucial element affecting all objective and subjective aspects of an individual. Thus, an Iranian individual has a religious identity along with modern and traditional identities and its impact should not be disregarded. To put in other words, religion has played a role in socialization process and determined individuals' habituses and attitudes towards death. According to the analysis presented, religiosity can explain the weak correlation between lifestyle and attitudes towards death; however, religion was not within the scope of this research and its impact was not controlled. Further studies are recommended to investigate and control this variable and to examine the findings of the present study. The lack of correlation between lifestyle and attitude towards death can be caused by the fact that, as Ericsson mentions, middle-aged adults are productive and creative and look for innovative and generative jobs. They are also involved in new fields to achieve important goals of their lives. In other words, these people have greater enthusiasm and tendency towards life and this leads to insignificant differences between them in terms of attitudes towards death.

The results revealed that there is a relationship between gender and attitudes towards death. Further, gender was a predictor for two types of attitude towards death in multivariable analysis. Due to differences between males and females' socialization processes, it can be claimed that the lifestyle and the habituses are different and individuals eventually adopt different attitudes towards death.

According to the results, there was no correlation between marital status and attitude towards death; however, the results of multivariate analysis of variance showed correlations between marital status and death avoidance, escape acceptance and neutral acceptance. Hence, the assumption is partly accepted. To explain this finding, it can be said that people in different fields acquire different habituses and accordingly adopt different attitudes towards death. Marital life creates its own specific field and habitus. Thus, married people hold attitudes different from other groups. Concerning different type of attitudes selected by married couples, it seems that this group has more problems and concerns compared to other groups. As a result, they have adopted a neutral attitude towards death and regarded death as a way to escape from their own problems.

A significant relationship was observed between level of education and two types of attitudes towards death (escape acceptance and neutral acceptance). Bourdieu believes that education is considered as a secondary habitus and it replaces and precedes the family habitus (Bonne Witz, 2012). Thus, people with different levels of 
education levels held different attitudes towards death. Regarding confirmed types of attitudes, it can be said that science is a modern phenomenon. Thus, individuals have lower levels of death acceptance as their level of education progresses.

There was no relationship between income and attitudes towards death; however, the regression analysis showed that there is a significant positive relationship between income and fear of death and neutral acceptance. In this case, groups of individuals with different income levels have their own habituses and ultimately form their own specific attitudes towards death.

To sum, the traditional and modern levels of lifestyles affects individuals' orientation towards death. Accordingly, individuals' attitudes towards death is not only dependent upon individual factors, but is also influenced by social and cultural factors. Evidently, individuals' attitudes towards death, especially near elderly individuals', plays a critical role in mental, psychological and social health of a society. Thus, concerning cultural factors such as lifestyle would decrease the adverse effects of negative attitudes towards death. In this regard, planning may be performed at micro and macro levels. Macro level planning requires social policy-makers' efforts and support to integrate traditional and modern practices in order to promote cultural programs, including leisure-time activities. At the micro level, effective steps can be taken to solve the problems associated with the future elderly by affecting individuals' habituses through enhancing the attractiveness of traditional cultural programs and encouraging them along with clarifying the information on death, sanity and health.

\section{References}

Azami, M. (2012). "The effect of occupational position on the lifestyle of female employees working in the Ministry of Cooperatives, Labour and Social Welfare", Business and Society, 149, pp. 56-46.

Norbert, E. (2006). The loneliness of the dying. Translated by Omid Mehregan and Saleh Najafi. Tehran: Game Noe.

IRNA News Agency, March 20, 2015, News ID: 81547525.

Aftab News Agency, April 6, 2014, News ID: 238274.

Poorgholami, M, Sohrabi Shekofti, N. and Samani, S. (2011). On the relationship between quality of life and attitude towards death in the elderly. National Conference on Psychology and Family Psychology

Bagherian, S., Iranmanesh, S. and Abbas Zadeh, A. (2009). "Comparison of Bam and Kerman nursing students' attitude about death and dying". Journal of qualitative Research in Health Sciences. 2010; 9 (1 and 2) :54-60

Bayengani, B., Irandoust, F. and Ahmadi, S. (2013). "Lifestyle from the perspective of sociology: An introduction to the understanding and analysis of the concept of lifestyle," Cultural Engineering, 8, pp. 74-56.

Bonnewitz, P. (2012). Lessons from the sociology of Pierre Bourdieu. (J. Jahangiri, Trans).

Jamshidiha, G. and S. Parastesh (2007). "Dialectic manner and field in Pierre Bourdieu's Theory of Action" Social Science, 30, pp. 32-2. 
Rasouli, M., (2013). Examining lifestyle factors in television commercials. Tehran, IRIB Research and Assessment Program Center.

Salamat News Agency, April 25, 2014, News ID: 110279

Ghaneirad, A. and Karimi, M. (2006). "Death and dying cultural plays (Case study: Imam Khomeini Hospital cancer patients)." Culture and Communication Studies, 2(5), 73-51.

Karimi, M. (2009). "Death and dying as cultural issues". Culture and Arts, 1, pp. 101-91.

Karimi, Y. (2007). Social Psychology. Tehran: PNU.

Giddens, A. (2009). .Modernity and self - Identity: Self and society in the late modern age. Translated by Naser Movafaghian. Tehran: Ney Publication Center.

Mahdavi Kani, M. S. (2007). "The concept of lifestyle and its scope in the social sciences", Journal of Cultural Research, 1(1), pp. $230-199$

Nosrati, S. and A. Zolfaghari (2012). "The impact of religiosity on the lifestyle of the youth in Tehran", Journal of Social Studies, 4(14), pp. 117-102.

Yousefi, A. and Tabei, M. (2011). "Experimental phenomenological study of the meaning of death for women in Mashhad". Strategy for Culture, 4(14 and 15), pp. 52-39.

Hamshahri Online News Agency, February 1, 2015, News ID: 286012.

Bourdieu, P., \& Wacquant, L. J. (1992). An invitation to reflexive sociology. University of Chicago press.

Carr, D. (2012). "Death and Dying in the Contemporary United States: What are the Psychological Implications of Anticipated Death?." Social and Personality Psychology Compass, 6(2), 184-195. DOI: 10.1111/j.1751-9004.2011.00416.x

Chistopolskaya, K., \& Enikolopov, S. (2013). "Defenses against the Fear of Death in Postsuicide." Procedia - Social and Behavioral Sciences, 86(0), 64-69. doi:10.1016/j.sbspro.2013.08.526

Christensen, V. T., \& Carpiano, R. M. (2014). "Social Class Differences in BMI among Danish Women: Applying Cockerham's health lifestyles approach and Bourdieu's Theory of lifestyle". Social Science \& Medicine, 112(0), 12-21. doi:10.1016/j.socscimed.2014.04.017

Duncan, I. J. (1999, September). "Some aspects of the relationship between society and the disposal of radioactive waste". In Uranium Institute 24th Annual Symposium, London.

Flint, J. (2003). "Commodification, Normalisation and Intervention: Cultural, Social and Symbolic Capital in Housing Consumption and Governance". Journal of Housing and the Built Environment, 18, 213-232. Doi: 10.1023/A:1025113329508

Jacobsen, M. H. (2013). Deconstructing death-Changing cultures of death, dying, bereavement and care in the nordic countries. Syddansk Universitetsforlag.

Kao, S. F., \& Lusk, B. (1997). "Attitudes of Asian and American graduate nursing students towards death and dying". International journal of nursing studies, 34(6), 438-443. DOI: http://dx.doi.org/10.1016/S0020-7489 (97)00038-2

Lavoie, J., \& Vries, B., (2004). Identity and Death: An Empirical Investigation. OMEGA, 48(3), 223243. doi: 10.2190/H2K9-15Q7-U7Q5-3CQA

Maria, M., Palo's, S., Kiriaki, S., Tatiana, S., Kostantinia, K., Eleni, M., \& Eleni, T. (2011). “Greek Nurses Attitudes towards Death". Global Journal of Health Science, 3(1), 224-230. doi:10.5539/gjhs.v3n1p224

Mellor, P. A. (1992). "Death in high modernity: the contemporary presence and absence of death". The Sociological Review, 4O(S1), 11-30. https://doi.org/10.1111/j.1467-954X.1992.tb03384.x

Nakagi, S., \& Tada, T. (2014). "Relationship between identity and attitude towards death in Japanese senior citizens". The Journal of Medical Investigation, 61, 103-117. Doi: 10.2152/jmi.61.103 
Parker, D. W. (2013). "The Relationship between Ego Integrity and Death Attitudes in Older Adults". American Journal of Applied Psychology, 2(1), 7-15. https://doi.org/10.11648/j.ajap.20130201.12

Routledge, C., \& Juhl, J. (2010). "When death thoughts lead to death fears: Mortality salience increases death anxiety for individuals who lack meaning in life". Cognition and Emotion, 24(5), 848-854. https://doi.org/10.1080/02699930902847144

Siyang, L., Xuedong, Y., Xiaoying, W., and Shihui H. (2014). "Reminders of mortality decrease midcingulate activity in response to others suffering". SCAN, 9(4), 477-486. doi: 10.1093/scan/nst010

Wong, P. T. P., \& Tomer, A. (2011). "Beyond Terror and Denial: The Positive Psychology of Death Acceptance". Death Studies, 35, 99-1. DOI:10.07481187/1080.2011.535377 